Discourse and Communication for Sustainable Education, vol. 6, pp. 110-126, 2015

\title{
Identification as Incentive to Care: Pre-service Teachers' Orientation Towards Inclusion in Nature
}

\author{
Inga Gedžūne \\ Daugavpils University, Latvia
}

\begin{abstract}
This study proposes identification with nature as a pedagogical technique in teacher education for sustainability to facilitate commitment to care about nonhuman nature, such care being an important underpinning of an inclusive and hence sustainable humannature relationship. 29 pre-service teachers participated in a series of learning activities which involved using identification with nature combined with creative forms of expression such as eco-story and eco-poetry to reflect on the human-nature relationship. Findings from qualitative content analyses of student-generated creative writings and subsequent evaluations of the proposed learning experience support the use of identification in learning about human-nature relationships to promote care for and inclusion in nature through nuanced awareness of similitude between the human and the nonhuman.
\end{abstract}

Keywords: inclusion in nature, identification, care, pre-service teacher education, sustainability

\section{Introduction}

The sustainability of human relationship with nature depends on how people define themselves with regards to the latter. Schultz (2000) distinguishes three ways of positioning which, I believe, underpin three different forms of human relationship with the environment that are best viewed as a continuum (Figure 1). As seen from the figure, low inclusion is underpinned by an egocentric positioning whereas high inclusion - by a biocentric positioning. According to Taylor (2000), the latter means that one identifies oneself as belonging to the Earth's community of life or, in other words, acknowledges one's connectedness and interdependence with other elements of the great living web. A biocentric positioning is an indicator of a sustainable quality in a relationship, which Huckle (1996) describes as such where no separation exists between humans and nature because humans perceive themselves as nature just like the creatures, things and environments that surround them. In such a sustainable relationship, a human being is seen as a part of nature, the latter being conceptualised as life and its support system. Thus, if society undertakes a course towards sustainability, it should aim for inclusion in the Earth's community of life. 


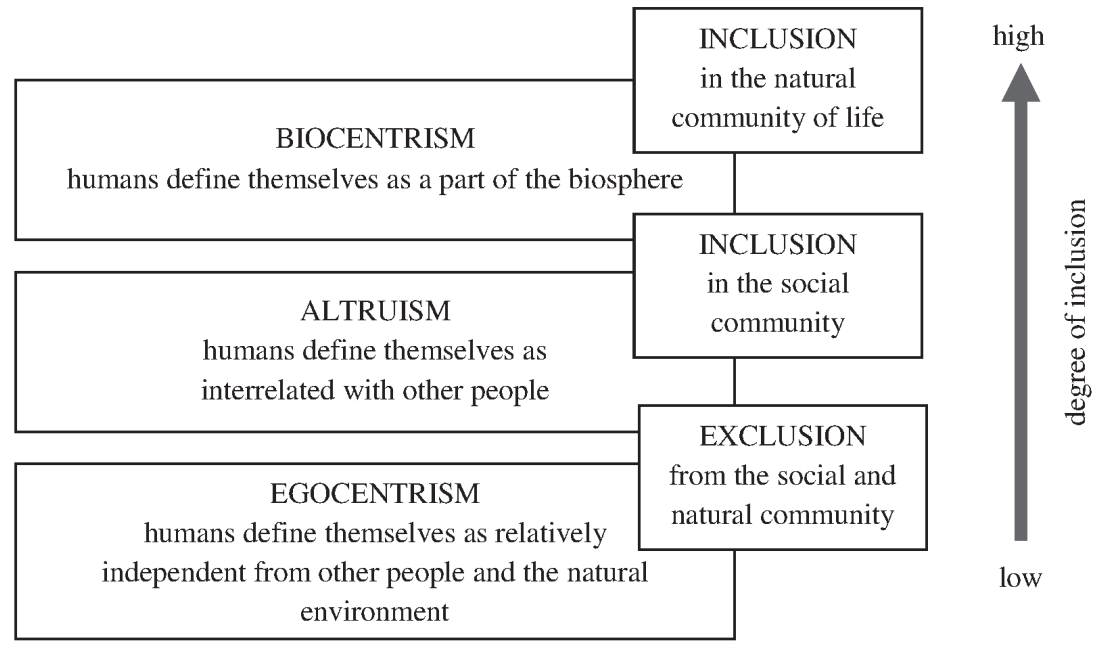

Figure 1. Egocentric, altruistic and biocentric positioning across the continuum of inclusion

According to philosophers (Rolston, 1988, 2000), quest towards sustainability and inclusion entails a re-examination of some pending, ethically charged questions, such as how to define ourselves as related to nature rather than as separated from it, how to adapt our lifestyles to nature rather than vice versa, how to act ethically with regards to nature, how to achieve harmonious coexistence underpinned by respect, responsibility and care. Education for sustainability is an important context where such questions should be debated and ways sought to orient the young towards establishing close or intimate (inclusive) rather than detached or estranged (exclusionary) relationships with the natural world (Berry, 1999).

Such a philosophical agenda means that educators should turn to philosophy for guidance on how to teach for and about sustainability and human inclusion in nature. The movement of deep ecology in particular can elucidate some of the above-mentioned educational concerns, most notably, by proposing identification with nature (Fox, 2000; Kals \& Maes, 2002; Attfield, 2003) as a pedagogical technique to facilitate inclusion through generating incentives to care for nonhuman otherness. Since care for nonhuman otherness is an essential feature of human inclusion in nature (Schultz, 2002), facilitation of inclusion in education for sustainability necessarily involves leading learners towards awareness of the importance of care - a task that can be achieved by using identification with nature. Naess (2000) defines identification as extension of the boundaries of one's ego (physical and psychic self) to include others from the natural world, which ultimately culminates in seeing oneself as a true part of all life, feeling a genuine, personal concern for its wellbeing and acting in ways to enhance the latter. This process, also known as extension of one's ecological self (Becker, 2009), builds on reflection, imagination and intuition in order to enter into another's situation and experience (Brennan, 2005, as cited in Kelly, 2006). Schultz (2000) argues that, by empathetically taking on the perspective of a natural unit, i.e. by trying to see the world through their eyes, it is possible to decrease the degree of separation between an individual's self and nature and thus render this self more inclusive and caring. 
Thus, identification emerges as a pathway towards human inclusion in nature, which should be pursued in education for sustainability. The latter is often described as pushing the boundaries of care and concern beyond the habitually immediate and personal towards a participative sense of solidarity with others, distant people, environments, species and future generations (Sterling, 1996). In other words, education for sustainability is focused on moving individuals forward along the continuum of inclusion (Figure 1) through fostering care for nonhuman nature because such care is a basic feature of human inclusion in nature. The phenomenon of inclusion has cognitive, affective and conative dimensions. It involves beliefs about belonging and a feeling of care, which find expression in willingly undertaken protective actions (Schultz, 2002). Philosophers argue that care is an inherent human trait (Eriksen, 2013) - we are genetically predisposed to care for others not only with reference to our personal interest, but also by taking on the perspective of another and doing what seems best from their standpoint (Attfield, 2003). It follows that care underpinned by identification is a vital human capacity, which should be recognised in pedagogical theory and tapped into in educational practice. The latter pathway was pursued in the study described in the present paper, which was conducted in the context of implementing teacher education for sustainability. Notably, the study aimed to involve pre-service teachers in identification with nature with a view to fostering care and thus orienting prospective educators towards inclusion in nature. The following research question was on the agenda: what are the advantages of using identification with nature in teacher education for sustainability in the context of reflection on the desired quality of the human-nature relationship?

\section{Methodology}

The present study is a fragment from a broader action research into my practice of implementing teacher education for sustainability at a regional university in the context of consecutive study courses 'Environmental Pedagogy' and 'Education for Sustainable Development', which span one academic year in pre-service teacher education programmes 'Preschool Teacher' and 'Basic Education Teacher'. I conceptualise action research as systematic reflection on practice with a view to better understanding or improving it (Bradbury \& Reason, 2003). Action research is seen as unfolding on two levels: (1) my as course tutor's inquiry into the practice of course implementation while seeking ways to orient pre-service teachers towards inclusion in nature and (2) pre-service teachers as course takers' inquiry into the actual and the desired quality of human relationship with nature, int. al. their personal relationship with it, with a view to making these more inclusive. My inquiry is thus unfolding around the students' inquiry which is facilitated via reflexive group assignments during seminars scheduled on alternating weeks with theoretical lectures.

The present paper describes a fragment of this action research - a phase in late March 2012 within the study course 'Education for Sustainable Development'. It involved 29 first-year female students aged 19-21. The time of the study marked the end of the second month of course acquisition. By that point, the meanings of the concept of sustainability and an education aimed at enhancing sustainable living had been covered in theoretical lectures and debated in reflexive seminars. 


\section{Data collection}

Learning is a process whereby people construct personal meaning out of their experiences (Dewey, 1966; Noddings, 1998) that are gained from interaction with the environment (Webb, Metha, \& Jordan, 2003). Hence, the pre-service teachers' learning about the complexities of the human nature relationship was rooted in their experiences of interaction with it.

Data for the present study were collected during a seminar within the above-described course 'Education for Sustainable Development'. The seminar in question followed a lecture about philosophical (holistic) underpinnings of sustainability. The grounds of inquiry were the participants' various experiences of interaction with nature, which are recognised in scientific discourse as a powerful means of shaping the way humans view and treat nature and position themselves relative to it (Kahn, 2002; Kellert, 2002; Orr, 2002; Tomashow, 2002) and advocated as a point of departure in environmental and sustainability education (Martin, 2007).

The students were encouraged to look back on their prior experiences of direct and vicarious interaction with nature and invited to imagine themselves as a natural unit plant, animal, habitat, natural phenomenon, etc. (in other words, to identify with it). The following successive stages of identification can be pinpointed in this process:

(A) 'My story'. While being in the role of a self-chosen natural unit, the students reflect on relationships with humans (contemplate questions such as how do you affect them, how do they affect you, how does it make you feel, how would you like to be treated) and write a short eco-story describing these relationships.

(B) 'My song'. Continuing in the chosen role of a natural unit, the students express themselves poetically from the adopted perspective - write a short eco-poem, possibly in blank verse, not necessarily rhymed or rhythmical, which would capture the essence of their relationships with humans. These poems are simply entitled 'My Song' and outline a concisely-put life story, a significant moment in existence, a message to the world, etc.

(C) 'My commitment'. Returning to their own 'selves', i.e. abandoning the previously assumed role of a natural unit, the students contemplate and write down three personal commitments that they plan to follow in order to better the lot of the subject they have just identified themselves with.

(D) 'My reflection'. The students reflect on their experience of identification individually and in pairs, orally and in writing - compare with whom they identified, how it made them feel, what their relationship with humans was like, what was common and what was different in their identification experiences.

Thus, identification was intertwined with reflection and articulation of reflexive insights via creative forms of expression in prose and poetry (stages A and B), which make use of sometimes rhythmical, emotionally charged, image-wise rich and evocative language. Creative forms of expression are a generally recognised qualitative research tool which permits to surface deeply internalised attitudes and ways of being (Mullett, 2008). They allow tapping into a particular way of knowing about the world, termed presentational knowing (Heron \& Reason, 2008), which encapsulates experience in 
vivid, expressive imagery. Creative forms of expression are recognised as a unique level of reflection about an individual's experience where it is described as if from within, with an emphasis on words which reveal the freshness of experience in a way that is authentic to the individual (Burchell, 2010). Such a way of reflection on experience permits to retain a long-term connection with it and leads to a generation of personally meaningful insights which can otherwise remain hidden from access (Burchell, 2010). Its usage has lately become a prominent trend in the qualitative research tradition. Denzin and Lincoln (2005) in particular advocate experiments with novel forms of expressing lived experience, including literary, poetic, autobiographical, multivoiced, conversational, critical, visual, performative and co-constructed representations. The above-described considerations underpinned the choice to organise my action research into the ways pre-service teachers' make sense of the human-nature relationship by combining identification, reflection and creative writing.

\section{Data analysis}

The 29 research participants identified with 23 different natural units and described this identification in their eco-stories and eco-poems. Since the activity took place in early spring, unsurprisingly, the 23 items include spring flowers typical for Latvian geographic conditions, such as snowdrop, European hepatica, narcissus and early purple orchid, also rose $(n=2)$, thistle, pot plant as well as other elements of plant life such as fir and chanterelle. Many representatives of the animal kingdom were also used by the students for identification, such as insects (bee $(n=2)$, butterfly $(n=2)$, grasshopper), fish (fish) and mammals (cat, dog, squirrel, hare). In one instance, a student identified with a fantastic creature - dragon. Three students chose to identify with habitats (air $(n=2)$ and forest) while three others opted for meteorological phenomena (rain, sun and lightning).

All student-generated texts (eco-stories, eco-poems, commitments and final reflections) were analysed with the method of qualitative content analysis. The inductive approach was applied which entails repeated readings of the text, identification of significant content units, their merging into categories and overarching themes (Granenheim \& Lundman, 2004).

An important limitation to this study is the necessity to use translation from the students' language (Latvian) into English for the purpose of writing this paper. Conversion of the student-generated texts into English was performed by me. The decision not to recruit help from outside was conscious and underpinned by the following considerations. Firstly, I felt it was important that the poems be translated by someone who was an insider in the study and therefore had a better understanding of what it was about. Secondly, I felt adequately qualified for the task, because I hold a degree in English philology with a teacher's licence and have been employed for seven years as a translator and interpreter in a research institute that specialises in educational research. Translation of the poems used as examples in the present paper posed the greatest difficulty. While translating, I regarded content as primary and manner as secondary. According to Abbs (2013), eco-poetry is exceptionally diverse in terms of composition patterns - it can take the form of flowing free verse or formal metre and rhyme, or even vacillate between the two. Therefore, what matters for analytic purposes is not the manner but the content. 
Hence, when dealing with the students' texts, the prime concern was first and foremost to preserve the idea and only then, whenever possible, to retain the form and rhythm originally suggested by the authors.

\section{Findings}

The findings from the study will be presented in four thematic sections, beginning with insights gleaned from the research participants' stories ('The stories from nature'), followed by the results derived from an analysis of their poems ('Singing nature's song'), continued with a review of the students' resolutions to treat their subject of identification in particular and nature in general in protective ways ('Committing to care') and concluding with an evaluation of the proposed learning experience by the students involved in it ('Lessons from identification').

\section{The Stories from Nature}

Direct experience of interaction is the grounds for shared stories of relationships between humans and nature (Martin, 2007). In the first part of the study, the students were invited to look back at such experiences with nature, identify themselves with a natural unit from this experience and write a story of relationship with humans from the perspective of their subject of identification. They were thus writing nature's story from its own standpoint.

The following question underlay my analysis of the student-generated nature's stories: what are the grounds for pre-service teachers' identification with nature? I therefore focused on scanning the student-generated texts for the dimensions of similitude between themselves as representatives of the human species and the subjects of their identification from the nonhuman living world. The following dimensions of assumed similitude between the human and the nonhuman (Table 1), as perceived by the research participants, emerged: (1) physical properties, (2) sentience in terms of ability to feel pain or pleasure, (3) emotional capacity, (4) patterns of social organisation, (5) purpose of existence, (6) explicit moral standing of a form of life.

Table 1.

Similitude as Grounds for Identification in Student-generated Nature's Stories (n=29)

\begin{tabular}{llc}
\hline \multicolumn{1}{c}{$\begin{array}{c}\text { Dimension of } \\
\text { similitude }\end{array}$} & \multicolumn{1}{c}{ Extracts from stories as examples } & Tally \\
\hline $\begin{array}{l}\text { Physical } \\
\text { properties }\end{array}$ & $\begin{array}{l}\text {...Although I look untouchable, prickly and fearsome, there will } \\
\text { always be people who will want to tear off my big leaf, which is like } \\
\text { a hand to humans... (Thistle story) }\end{array}$ & 2 \\
\hline Sentience & $\begin{array}{l}\text {...But a little boy was playing ball, and he hit me. It hurt so much... } \\
\text { (Rose story) }\end{array}$ & 7 \\
\hline $\begin{array}{l}\text { Emotional } \\
\text { capacity }\end{array}$ & $\begin{array}{l}\text {...Once human chattering woke me up, I opened my eyes and saw } \\
\text { a lady and a girl looking at me, I got so frightened, and in a couple } \\
\text { of minutes I was in the hands of this screaming girl, I was petrified... }\end{array}$ & 24 \\
& (Dog story) & \\
\hline
\end{tabular}


Sequel to Table 1.

\begin{tabular}{llc}
\hline \multicolumn{1}{c}{$\begin{array}{c}\text { Dimension of } \\
\text { similitude }\end{array}$} & \multicolumn{1}{c}{ Extracts from stories as examples } & Tally \\
\hline $\begin{array}{l}\text { Patterns of social } \\
\text { organisation }\end{array}$ & $\begin{array}{l}\text {...I'm a little bee. I live together with my sisters in a small, } \\
\text { comfortable home. We have a big and friendly family... (Bee story) }\end{array}$ & 8 \\
\hline $\begin{array}{l}\text { Purpose of } \\
\text { existence }\end{array}$ & $\begin{array}{l}\text {...Now, on hot summer days when it hasn't rained for quite a while, } \\
\text { I refresh fields, meadows and all living creatures. I water the fields } \\
\text { so that the grass and flowers don't whither but rather grow lush } \\
\text { and verdant. (..) they [people] shouldn't think I fall on a whim; } \\
\text { rather, [I do it] because it is also good for them - so that cows and } \\
\text { other herbivores have something to eat... (Rain story) }\end{array}$ & \\
\hline $\begin{array}{ll}\text { Explicit moral } \\
\text { standing of life }\end{array}$ & $\begin{array}{l}\text {...I'd like it if people treated me with respect and with love, and also } \\
\text { with responsibility, because I too am a living being, just like humans } \\
\text { are. People have no right to scorn or hurt me, because I too want to }\end{array}$ & 3 \\
& live... (Fish story) & \\
\hline
\end{tabular}

Thus, the research participants exhibit an awareness of specific patterns of similarity between humans and nonhumans in the community of life. The relatively wide range of similarities identified in the student-generated texts suggests a sense of likeness with and closeness to nature. These assumptions about similarity and connectedness between humans and nature carry significant implications to the ethical underpinnings of human treatment thereof. It is generally accepted that humans possess an intrinsic moral value (Palmer, 2003; Elliott, 2009; Keller, 2010), i.e. are worthy of respect and care on mere account of being what they are. If we assume that nature is in some vital way(s) 'like' us, we are justified in attributing a similar moral status to it. In other words, if nature is essentially 'like' humans, it warrants similar moral considerations in the way it is treated. Thus, recognition of similitude permits to extend the boundaries of care as a morally requisite form of treatment from the human to the nonhuman or, in other words, include nature in our scope of care. Findings from this study suggest that using identification in teacher education for sustainability goes some way to facilitating such recognition and inclusion.

\section{Singing nature's song}

The participant-generated texts that will be analysed in this section are examples of eco-poetry - a term used to describe creative writings of particular content rather than style. According to Abbs (2013), eco-poetry serves to embody the implicit, intangible and yet fundamental link between nature and the human psyche - to illuminate "the way in which each thing and each event is connected to the intricate and reciprocal web of life" (p. 50). In this perspective, records of eco-poems are delicate and nuanced material illustrations of the minutiae of the relationship between humans and the rest of nature. Analysis of the research participants' poems was focused on picking out the main themes in their assumptions about the human nature relationship. The analysis surfaced three broad thematic strands with intertwined threads of supporting categories, which are outlined in Figure 2.

Thus, in their eco-poems the students addressed controversial ethical issues of how humans regard nature in relation to themselves and how they should be doing it, how humans actually treat nature and what this treatment should be like. Is belonging (inclu- 
sion) or detachment (exclusion) a feature of relationships in the natural world? Is care and protection or disregard and destruction the way to treat nature? Is nature equal to humans in terms of internal dignity and respect that it commands or does it only gain meaning and purpose in relation to humans? These deeply ethical, poignant questions were never asked to the research participants; rather, the pre-service teachers were those who implicitly posed them in their poems - a form of expressing reflexive insights which is free of any constraints with regards to rhyme or metre. Poetic expression (brief haiku-like flickers or somewhat longer creations in blank verse), in this instance becomes the means of capturing and conveying deep impressions and intuitions which derive from the participants' life experiences; a way of putting into words what they subjectively feel and believe to be true about the world.

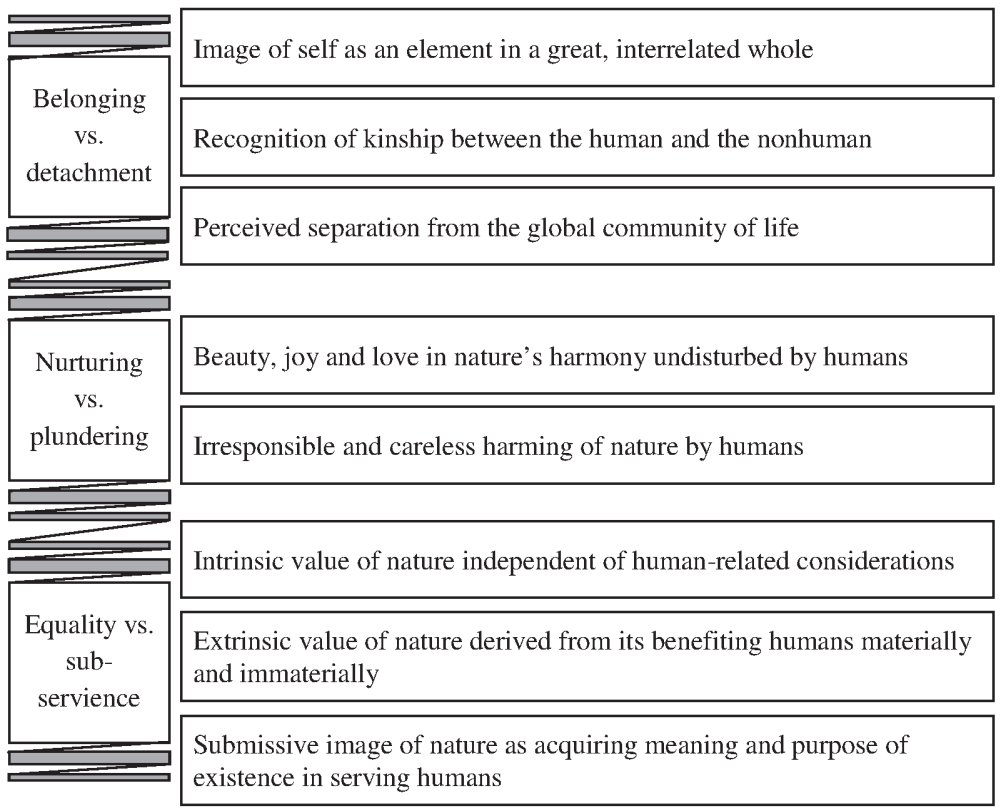

Figure 2. Strands and threads of meaning in the research participants' poetic expression

The pool of data suggests that the research participants consider the natural state of relationships in the Universe to be inclusive (as evidenced in thematic threads of interrelatedness and kinship):

Greatness of forest and softness of moss,

Softness of moss and sunlight through branches,

Sunlight through branches and warmth within me,

I am happy where I am.

$* * *$

In the wide Universe, a tiny $M E$.

$* * *$

A bare drop of moonlight.

(Chanterelle song) 
According to Abbs (2013), bringing out the inclusivity between humans and the rest of nature is the main thematic strand of eco-poetry. And yet, eco-poetry exists not only to affirm the inherent matrix of connections between the human and the nonhuman in nature but also to expose instances when these invisible bonds are severed and to suggest the dire consequences of doing so (Abbs, 2013). The poems written in the present study follow this trend and describe instances when the inherent links in the community of life are not appreciated:

Surrounded by wide open spaces

I stand here so mighty, so great,

Yet all alone in this world.

No enemies,

No benefactors.

Such is my life,

Such are the days of a lonely thistle.

(Thistles song)

This sense of detachment underpins an ethically questionable, harmful treatment of nature, which the students lament in their poems, grieving over the fact that inclusion has not yet become a universally accepted form of relationships between humans and nonhumans:

Sit.
Eat.
Throw.
Laugh.

While I

Stand.

Cry.

Wait

For your conscience to finally awaken.

(Forest song)

The data suggest that this problem can only be solved if humans radically change the way they perceive themselves with regards to nature and nature with regards to themselves. What is required is a recognition of our inherent kinship; a profound acknowledgement of all life having sprung from one source and thus being essentially alike. As one student writes in her Hare song, "we are also nature's children - just as you are". Kinship entails affinity and care. According to Noddings (1984), care requires a willingness to act in ways that increase the wellbeing of the other, and such willingness is dictated by relatedness. We care for those whom we are related to, whom we consider family or kin, and we are moved to act in ways that would preserve or even increase their wellbeing. Thus, key to bettering human relationships with the rest of the natural world is recognition of our kinship with it, which means appreciation of closeness, similarity, connection, relatedness. Deep ecologists (Fox, 2000; Naess, 2000; Orr, 2002; Tomashow, 2002) argue that it can be achieved via identification. The latter thus emerges as a valuable pedagogical technique to promote inclusion. 


\section{Committing to Care}

Additional evidence in favour of using identification to teach and learn about inclusion in nature is found in an analysis of students' resolutions following the identification experience. The 29 research participants each made three commitments resulting in the totality of 87 resolutions in the inquiry group. Codes for analysis of these commitments were inspired by Noddings' (1984) conceptualisation of care towards otherness (in this specific instance, care towards nature). Noddings recognises the following preconditions for care: conceptual and emotional understanding of the other, recognising the intrinsic value of the other and willingness to act for the good of the other. These insights regarding the phenomenon of care served as the basis for designing the system of categories to analyse the research participants' commitment to care for nature (Table 2).

Table 2.

Commitment to Care for Nature Following Identification

\begin{tabular}{llc}
\hline \multicolumn{1}{c}{ Categories } & Tally \\
\hline Cognitive-axiological dimension of care & Appreciative value judgements about nature & 11 \\
\hline Affective dimension of care & Feeling an affinity with nature & 20 \\
\hline Action dimension of care & Refraining from doing harm & 23 \\
\hline & Doing good & 23 \\
\hline & Teaching others to care & 10 \\
\hline
\end{tabular}

Thus, following an experience of identification with a natural element, the research participants committed themselves to caring for the subject of their identification in particular as well as for nature in general. They substantiated their commitments by acknowledging the intrinsic value of nature: "I resolve never to think that I'm the king of the world and that everything and everyone bows to me. All nature is valuable!" Another student claims: "I pledge myself to honour and respect this little creature [chanterelle] because it is a living being". These examples illustrate how the research participants profess their belief in the ultimate human responsibility to cherish life as a precious treasure valuable in and of itself. Such an orientation is an important step towards the students' developing a caring disposition towards the world, which will support their inclusion in nature.

As seen from Table 2, another insight from an analysis of the research participants' commitment to care made after identification with nature is related to the affective dimension of care: care as not being indifferent, which presupposes emotional involvement. Multiple references can be found in theoretical literature about this aspect of care towards nature. Individuals are described as caring for nature if they experience feelings of regard towards it (Martin, 2007), affection towards it (Schultz, 2002), affiliation with it (Tomashow, 2002), concern for it (Taylor, 2011). References to nurturing such emotional bonds are plentiful in the research participants' commitments. For instance, "I resolve to love and admire these beautiful flowers [early purple orchid]", "I resolve to rejoice in them [European hepatica] every time I see them", "I commit myself to love all that blossoms in spring". Such emotional involvement is an important underpinning of care, and the experience of identification appears to have triggered it in the research participants.

Finally, care is also conceptualised as action. According to Becker (2009), cognitive valuations of and an affective disposition towards nature make humans act or refrain 
from acting because of concern for its wellbeing. The action dimension of care appeared as most pronounced in the research participants' commitments towards nature. First, the students pledge themselves to abstain from harmful actions: "I resolve not to pollute the environment, forests, meadows, etc.", "I resolve not to harm it [thistle] in any way and just let it be". Secondly, they commit to acting for the good of nature, such as "I pledge myself to tend the narcissus, to water it", "I commit myself to clean the surroundings of my house", "I resolve to participate in annual collective clean-up campaigns in my community". As seen from these examples, both taking action and refraining from action are either more or less general - focused on the subject of the students' identification or extended to the broader context of the environment. The latter indicates a holistic way of thinking, which acknowledges the interrelatedness of everything in nature and the fact that by acting for the good of the environment as such it is possible to contribute to the wellbeing of its elements. Last but not least, the pre-service teachers resolve to educate others about the need to care for nature: "I resolve to reprimand everyone who treads on these flowers [early purple orchids]", "I commit myself to tell children that all living creatures feel pain", "I resolve to teach children to treat nature well". This educative commitment emerges as particularly important and promising in view of the research participants' future role as teachers for sustainability.

\section{Lessons from Identification}

The research participants' evaluation of their experience of identification with nature highlights the following advantages of such learning about the human-nature relationship:

Indulging learners' interests. The students almost universally cast the proposed learning experience as "interesting". It appears to have appealed to them and to have seemed exciting. Thus, identification emerges as a way of learning about the intricacies of human-nature relationships which students find personally relevant and fascinating. Such approach to teacher education appears conductive to involving learners, drawing them in, engaging them and thereby fostering a fuller and more meaningful participation in the learning process. Such apprehended, personally meaningful learning is crucial in education for sustainability (Evernden, 1985; Whitehouse, 2008; Gadotti, 2010) which is not concerned with memorisation of ready-made knowledge but rather focuses on construction of personally-significant insights about relational issues and encouraging a deeply internalised commitment to sustainable living.

Introducing novelty. One student in particular described the experience as "something unheard and untried - to step into someone else's shoes". It means incorporating identification in teacher education for sustainability can help introduce a welcome diversity in the students' learning, expanding the horizons of their perception of what learning for sustainability can be like. Novelty is vital in education for sustainability, which is concerned not with regurgitating formulaic truth-statements about the world, but rather with questioning, critique, contemplation of alternative meanings and construction of new ideas, perspectives and solutions (Kahn, 2010). It has become generally recognised that currently universities, besides diffusing information, need to produce new knowledge and encourage new ways of looking at habitual phenomena (Orr, 1992; Gadotti, 2010; King, 2010). Thus, seeking new ways of teaching and learning about the human-nature relationship (Whitehouse, 2008) and looking for novel ways of incorporating sustainability related issues in educational practice (Hernandez \& Mayur, 2000) is high on the 
agenda of nowadays education. This paper seeks to contribute to these initiatives by suggesting a way of learning about and for sustainability which involves identification with nature and is judged by learners as novel in form and facilitating examination of previously unexplored perspectives.

Deepening of insight. Sustainability oriented education should invite learners to think deeply and critically about complex, relational issues, about their values, attitudes, actions and relationships (Huckle, 1996; Hernandez \& Mayur, 2000; Kelly, 2006; King, 2010). Half of the students to evaluate the proposed learning experience of identification with nature report it to have significantly deepened their way of looking at the humannature relationship. For instance, one student claims: "It made me think deeply, not only about the purple orchid, but also about all the plants!!!” Another student details the deepening of her understanding: "I realised that people are not the "the centre of the Universe'; that plants and animals are also important. Environment complements us". Using poetic expression in particular appears to have enabled them to communicate a profoundly meaningful message impossible to convey otherwise: "I enjoy writing haiku because you can write something seemingly illogical and yet put a very deep idea in it". Thus, an experience of identification with nature and the following opportunity to reflect on it and cast the fruits of this contemplation in a poetic form emerge as a powerful way of deepening the learners' perspective on an issue of concern.

Cherishing creativity. It has become generally acknowledged (Hernandez \& Mayur, 2000; Kelly, 2006; Watson, 2007; King, 2010; Vandenkendelaere, 2011; Zarin Shoja \& Mahdaviniania, 2011) that tapping into the learners' creative potential rather than suppressing their imagination and creativity is of paramount importance in a sustainability oriented education which seeks to enable the development of wise solutions to support our living together in the natural and social world in a mutually satisfactory manner. With regards to the proposed learning experience, many students evaluate it as nurturing their creativity and facilitating its expression. For instance, one student notes: "I really liked this seminar because it let me think creatively and express myself". Others commend the "creative tasks", admit the learning session to have been "filled with creativity" and to have enabled them "to feel creative".

Catering for learners' emotionality. Several pre-service teachers speak about the welcome effects of the learning experience on their emotional state. They describe it as permitting "to relax and express [their] feelings", "to experience positive emotions" and leaving them "positively charged". It is common knowledge that humans are fundamentally emotional, feeling beings. Our very experience of the world is always emotionally coloured (Reisenzein \& Döring, 2009). Therefore, emotional involvement in reflexive processes at the core of action research is considered to be particularly important if such reflection is to be meaningful and insightful (Leitch \& Day, 2000). Also, the need to address the learners' emotionality when implementing education for sustainability is extensively discussed in theoretical literature. Thus Martin (2007) argues that, since the ultimate goal of education for sustainability is to inspire sustainable practices, teachers cannot disregard their learners' emotionality for emotions are a powerful motivator for action. In other words, education should move learners to be emotionally predisposed to act in ways that are deemed appropriate in a given culture at a given time. This standpoint is shared by several other scholars (Hernandez \& Mayur, 2000; Reason, 2007). For instance, King (2010) maintains that environmental education and education for sustainability should nourish a sense of wonder, love, hope, sensitivity and creativity in 
order to promote community, responsibility and belonging, grounded in a sense of the world being whole and everything and everyone in it interrelated in a joint web of life. Feedback from learners in the present study suggests that identification with nature to contemplate the intricacies of the human-nature relationship appears to be such an emotionally moving and nourishing learning experience.

Critique of the proposed identification experience was scarce. Only one recommendation for improvement was voiced - to afford more time to discuss the newly emerged insights with peers in order to exchange and compare the reactions to such a way of learning. Granted, such an opportunity was provided for about a quarter of an hour. Yet it appears to have been insufficient to some, and future repetitions of this approach would warrant additional time for discussion among learners. Indeed, reflection and discussion are widely recognised as the two pillars of education for sustainability (Kals \& Maes, 2002; Moore, 2005; Miles, Harrison, \& Cutter-McKenzie, 2006; Whitehouse, 2008; King, 2010) as learners are led to try and make sense of sustainability related phenomena and concepts that name them (Kahn, 2010) as well as contemplate the ethical underpinnings of multiple ways of being and relating in the global community (Huckle, 1996). Sunley and Locke (2002) agree that education should enable learners to become aware of the values they hold, and such awareness is triggered by reflection and discussion. Thus, education for sustainability should create spaces for learners to engage in reflection and discussion of their values orientations and the compatibility of these with the goal of sustainable living. Do we embrace the values of love, care, respect and responsibility towards life or do we value our own egos - our individual profit and wellbeing above all else? Such an opportunity was provided in this study, which involved the students in drawing on their experience of direct or vicarious interaction with nature to enter into an imagined situation of encounter from the perspective of an 'other' from nature. Feedback from the students suggests the need to support such learning via identification with generous time for subsequent reflection and discussion in which to contemplate what this learning experience means to the learner and what valuable lessons can be drawn from it. Failing that, the reaching of the educational goal of identification (enriching the learners' perspectives on the human-nature relationship and orienting them towards inclusion via incentive to care) should become problematic.

\section{In conclusion}

The learning experience described in this paper can be regarded as ethically focused, i.e. aiming to help pre-service teachers develop the virtue of phronesis, which is conceptualised in theoretical literature (Birmingham, 2003) as ability to judge and act wisely for the benefit of the common good of oneself and others. In the present context, this 'good' is building sustainable relationships between humans and nonhumans in the global community of life. The virtue of phronesis entails an emotional involvement with the needs and interests of others, and to actually appraise such needs one must feel true concern for them and their circumstances (Carr, 2007). Such concern or care is generated by entering into their situation, trying to see it from their perspective, and this process is emotional no less than it is rational. The above-described learning experience of identification aimed to achieve this goal - create and sustain incentives to care for nonhuman otherness, which would support an inclusive way of being in a sustainable relationship between humans and the rest of nature. 
The findings from the study suggest the following conclusions. Firstly, the use of identification with nature combined with creative forms of expression in teacher education for sustainability is appreciated by learners who consider it as indulging their interests, cherishing their creativity, deepening their reflexivity, catering for their emotionality and introducing novelty in the learning process. This appreciative feedback from learners casts identification with nature in a favourable light as a valuable way of organising pre-service teachers' learning about the complexities of the human-nature relationship.

Secondly, the use of identification in learning about the intricacies of the humannature relationship within the broader context of teacher education for sustainability appears to foster awareness among pre-service teachers of a multi-dimensional similitude between people and the rest of nature, which pushes the boundaries of care to include the nonhuman. The research participants come to make sense of the human-nature relationship in terms of kinship, which involves care in terms of not being indifferent but feeling affection and joy from relatedness and togetherness as well as empathising with the other's suffering. Thus, identification with nature as a pedagogical technique is likely to orient learners towards care, which underpins an inclusive and hence sustainable relationship between people and nature.

Thirdly, identification with nature followed by creative writing to reflect on this learning experience is found to encourage a contemplation of ethically charged controversial questions with regards to human treatment of nature as well as to facilitate the capturing and conveying of deep impressions and intuitions which derive from the participants' life experiences. It is a valuable educational experience because learners are able to contemplate alternative ways of framing an issue of concern.

Fourthly, identification combined with creative writing appears to foster commitment to care for nonhuman otherness, i.e. acknowledge its intrinsic value, become deeply and personally emotionally involved with it and show willingness to act ethically for its benefit. The avowed course of action is both individual (refraining from doing harm to the nonhuman other and enhancement of their wellbeing) and expanding into the learners' relationships with other humans (educating others about the proper way of treating nonhuman nature).

Lastly, it remains to be said that this paper describes insights from a small-scale qualitative study, which precludes abstract generalisation across contexts. Yet it is to be hoped that the findings discussed here can to some degree illuminate practice in similar situations and give educators some much-needed inspiration as they seek better ways to transform the dream of sustainability into reality. It is my firm belief that this goal can only be reached by people who, truly and deeply, care; whose concern expands beyond the boundaries of ego or the likewise limiting species perspective to include the nonhuman. It means that we must become ultimately inclusive of all life or, as discussed in the introduction to this paper, move upwards along the continuum of inclusion. It being a long journey, every step counts. Arguably, identification with nature as a pedagogical technique can bring us a stride closer.

\section{Acknowledgement}

This work has been supported by the European Social Fund within the project "Support for the implementation of doctoral studies at Daugavpils University, 2nd stage”, agreement No. 2012/0004/1DP/1.1.2.1.2/11/IPIA/VIAA/011. 


\section{References}

Abbs, P. (2013). New voices. Resurgence \& Ecologist, 278, 50-51.

Attfield, R. (2003). Environmental ethics: An overview for the twenty-first century. Cambridge: Polity Press.

Becker, G. K. (2009). Je suis le grand tout: Respect for nature in the age of environmental responsibility. In K.-T. Ip (Ed.), Environmental ethics: Intercultural perspectives (pp. 23-42). Amsterdam and New York: Rodopi.

Berry, T. (1999). The great work: Our way into the future. New York, USA: Bell Tower. Birmingham, C. (2003). Practicing the virtue of reflection in an unfamiliar cultural context. Theory into Practice, 42(3), 188-194. DOI: 10.1207/s15430421tip4203_4.

Bradbury, H., \& Reason, P. (2003). Action research: An opportunity for revitalizing research purpose and practices. Qualitative Social Work, 2(2), 155-175. DOI: 10.1177/1473325003002002003.

Burchell, H. (2010). Poetic expression and poetic form in practitioner research. Educational Action Research, 18(3), 389-400. DOI: 10.1080/09650792.2010.500096.

Carr, D. (2007). Character in teaching. British Journal of Educational Studies, 55(4), 369-389. DOI: 10.1111/j.1467-8527.2007.00386.x.

Denzin, N. K., \& Lincoln, Y. S. (2005). Introduction: The discipline and practice of qualitative research. In N. K. Denzin \& Y. S. Lincoln (Eds.), Handbook of qualitative research (pp. 1-32). London: Sage Publications.

Dewey, J. (1966). Democracy and education. New York: The Free Press.

Elliot, R. (2009). The normative side of nature. In K.-T. Ip (Ed.), Environmental ethics: Intercultural perspectives (pp. 11-21). Amsterdam and New York: Rodopi.

Eriksen, K. G. (2013). Why education for sustainable development needs early childhood education: The case of Norway. Journal of Teacher Education for Sustainability, 15(1), 54-62. DOI: 10.2478/jtes-2013-0005.

Evernden, N. (1985). The natural alien: Humankind and environment. Toronto, Buffalo and London: University of Toronto Press.

Fox, W. (2000). Transpersonal ecology and the varieties of identification. In J. Benson (Ed.), Environmental ethics: An introduction with readings (pp. 253-262). London and New York: Routledge.

Gadotti, M. (2010). Reorienting education practices towards sustainability. Journal of Education for Sustainable Development, 4(2), 203-211. DOI: 10.1177/0973408210 00400207.

Granenheim, U. H., \& Lundman, B. (2004). Qualitative content analysis in nursing research: Concepts, procedures and measures to achieve trustworthiness. Nurse Education Today, 24, 105-112.

Hernandez, C., \& Mayur, R. (Eds.) (2000). Pedagogy of the Earth: Education for a sustainable future (2nd ed.). Mumbai: International Institute for Sustainable Future.

Heron, J., \& Reason, P. (2008). Extending epistemology within a co-operative inquiry. In P. Reason \& H. Bradbury (Eds.), Sage handbook of action research: Participative inquiry and practice (2nd ed.) (pp. 366-378). London: Sage Publication.

Huckle, J. (1996). Realizing sustainability in changing times. In J. Huckle \& S. Sterling (Eds.), Education for sustainability (pp. 3-17). London: Earthscan Publications Ltd.

Kahn, P. H., Jr. (2002). Children's affiliations with nature: Structure, development, and the problem of environmental generational amnesia. In P. H. Kahn, Jr. \& 
S. R. Kellert (Eds.), Children and nature: Psychological, sociocultural and evolutionary investigations (pp. 93-116). Cambridge and London: The MIT Press. Kahn, R. (2010). Critical pedagogy, ecoliteracy and planetary crisis: The ecopedagogy movement. New York: Peter Lang.

Kals, E., \& Maes, J. (2002). Sustainable development and emotions. In P. Schmuck \& P. W. Schultz (Eds.), The psychology of sustainable development (pp. 97-122). Boston, Dordrecht and London: Kluwer Academic Publishers.

Keller, D. R. (2010). Introduction. In D. R. Keller (Ed.), Environmental ethics: The big questions (pp. 1-24). Chichester: Blackwell Publishing Ltd

Kellert, S. R. (2002). Experiencing nature: Affective, cognitive and evaluative development in children. In P. H. Kahn, Jr. \& S. R. Kellert (Eds.), Children and nature: Psychological, sociocultural and evolutionary investigations (pp. 117-151). Cambridge and London: The MIT Press.

Kelly, P. (2006). Learning for sustainable futures: One intervention. Journal of Future Studies, 10(3), 1-14.

King, U. (2010). Earthing spiritual literacy: How to link spiritual development and education to a new Earth consciousness. Journal of Beliefs and Values, 31(3), 245260. DOI: $10.1080 / 13617672.2010 .520998$.

Leitch, R., \& Day, C. (2000). Action research and reflective practice: Towards a holistic view. Educational Action Research, 8(1), 179-193.

Martin, P. (2007). Caring for the environment: Challenges from the notions of caring. Australian Journal of Environmental Education, 23, 57-64.

Miles, R., Harrison, L., \& Cutter-Mackenzie, A. (2006). Teacher education: A diluted environmental education experience. Australian Journal of Environmental Education, 22(1), 49-59.

Moore, J. (2005). Is higher education ready for transformative learning? A question explored in the study of sustainability. Journal of Transformative Education, 3(1), 76-91. DOI: $10.1177 / 1541344604270862$.

Mullett, J. (2008). Presentational knowing: Bridging experience and expression with art, poetry and song. In P. Reason \& H. Bradbury (Eds.), Sage handbook of action research: Participative inquiry and practice (2nd ed.) (pp. 450-461). London: Sage Publication.

Naess, A. (2000). Identification, oneness, wholeness and self-realization. In J. Benson (Ed.), Environmental ethics: An introduction with readings (pp. 243-251). London and New York: Routledge.

Noddings, N. (1984). Caring: A feminine approach to ethics and moral education. Berkeley, CA: University of California Press.

Noddings, N. (1998). Philosophy of education. Boulder, CO: Westview Press.

Orr, D. W. (1992). Ecological literacy: Education and the transition to a postmodern world. Albany, NY: State University of New York Press.

Orr, D. W. (2002). Political economy and the ecology of childhood. In P. H. Kahn, Jr. \& S. R. Kellert (Eds.), Children and nature: Psychological, sociocultural and evolutionary investigations (pp. 279-303). Cambridge and London: The Massachusetts Institute of Technology Press.

Palmer, C. (2003). An overview of environmental ethics. In A. Light \& H. Rolston III (Eds.), Environmental ethics: An anthology (pp. 15-37). Malden, Oxford, Victoria and Berlin: Blackwell Publishers Ltd. 
Reason, P. (2007). Education for ecology: Science, aesthetics, spirit and ceremony. Management Learning, 38(1), 27-44. DOI: 10.1177/1350507607073021.

Reisenzein, R., \& Döring, S. A. (2009). Ten perspectives on emotional experience: Introduction to the special issue. Emotion Review, 1(3), 195-205. DOI: 10.1177/ 1754073909103587.

Rolston, H. III. (1988). Environmental ethics: Duties and values in the natural world. Philadelphia, PA: Temple University Press.

Rolston, H. III. (2000). Can and ought we to follow nature? In J. Benson (Ed.), Environmental ethics: An introduction with readings (pp. 237-242). London and New York: Routledge.

Schultz, P. W. (2000). Empathizing with nature: The effects of perspective taking on concern for environmental issues. Journal of Social Issues, 24(3), 391-406.

Schultz, P. W. (2002). Inclusion with nature: The psychology of human-nature relations. In P. Schmuck \& P. W. Schultz (Eds.), The psychology of sustainable development (pp. 61-78). Boston, Dordrecht and London: Kluwer Academic Publishers.

Sterling, S. (1996). Education in change. In J. Huckle \& S. Sterling (Eds.), Education for sustainability (pp. 18-39). London: Earthscan Publications Ltd.

Sunley, R., \& Locke, R. (2010). Exploring UK secondary teachers' professional values: An overview of the literature since 2000. Educational Research, 52(4), 409-425. DOI: $10.1080 / 00131881.2010 .524751$.

Taylor, P. W. (2000). Respect for nature. In J. Benson (Ed.), Environmental ethics: An introduction with readings (pp. 215-222). London and New York: Routledge.

Taylor, P. W. (2011). Respect for nature: A theory of environmental ethics. Princeton, USA and Woodstock, UK: Princeton University Press.

Tomashow, C. (2002). Adolescents and ecological identity: Attending to wild nature. In P. H. Kahn, Jr. \& S. R. Kellert (Eds.), Children and nature: Psychological, sociocultural and evolutionary investigations (pp. 260-278). Cambridge and London: The Massachusetts Institute of Technology Press.

Vandenkendelaere, B. (2011). A definition of excellence: Opportunity for a pit stop? Journal of the European Higher Education Area, 2, 49-64.

Watson, J. (2007). Spiritual development: Constructing an inclusive and progressive approach. Journal of Beliefs and Values, 28(2), 125-136. DOI: 10.1080/13617670 701485698.

Webb, D., Metha, A., \& Jordan, K. F. (2003). Foundations of American education (4th ed.). New Jersey, Columbus and Ohio: Merril Prentice Hall.

Whitehouse, H. (2008). "EE in cyberspace, why not?" Teaching, learning and researching tertiary pre-service and in-service teacher environmental education online. Australian Journal of Environmental Education, 24, 11-21.

Zarin Shoja, E., \& Mahdaviniania, M. (2011). Mother Nature's tongue language education for promoting environmental sensitivity. In Proceedings of the international conference The Future of Education, 16-17 June 2011 (pp. 26-31). Florence: Simonelli Editore University Press.

Correspondence concerning this paper should be addressed to Inga Gedžūne, Daugavpils University, Latvia. Email: ingint@inbox.lv 